\title{
FEDERALISM AND THE 'ONE-PERSON ONE-VOTE PRINCIPLE': POLITICAL ACCOMMODATION IN CYPRUS AND THE ANNAN PLAN
}

\section{by Gavin Moore}

Department of Political Science, Queens University Belfast, Ireland Email: gmoore13@qub.ac.uk

\begin{abstract}
The 'one-person one-vote principle' (OPOV) seems to be an intuitively appealing principle, one that is procedurally fair by ensuring equality in votes for all and contributes to the proper functioning of democratic states. Although commonly cited as a cornerstone of democracy, this article argues that OPOV can be a dangerous principle in societies divided by group conflict. Minorities face permanent exclusion, and thus cannot protect their own interests, leading to resentment and destabilization. Moreover, deviation from OPOV is not uncommon in political accommodation, especially in federal arrangements. Opponents of deviation argue that it is both undemocratic and dysfunctional having potentially damaging implications for reconciliation. This article examines these claims in the case of Cyprus under the federal arrangements of the Annan plan. After discussing federalism and Cypriot politics, the article analyses philosophical and international positions on deviation from OPOV in order to assess whether deviation can be considered undemocratic, arguing that whilst not always procedurally fair or equal, deviation should be considered democratic if it encourages the effective participation of minorities. The article then examines the provisions within the Annan Plan to argue that its deviations from the OPOV principle do not hinder its functionality. The article concludes by arguing federalism and deviation from OPOV encourage political accommodation and offer the best chance of reconciliation between Greek Cypriots and Turkish Cypriots.
\end{abstract}

Keywords: Cyprus, Annan plan, voting, minority participation

Moore, G. 2011, "Federalism and the 'one-person one-vote principle': Political Accommodation in Cyprus and the Annan plan", Federal Governance, vol. 8 no. 2, pp. 29-41. 


\section{About Federal Governance}

Federal Governance is an online graduate journal on theory and politics of federalism and multilevel governance. Its mandate is to engage the global federalism community and reach out to outstanding graduate students interested in federalism and multi-level governance. By providing a platform for graduate students to have early success in their careers, Federal Governance seeks to promote and sustain interest in federalism and multi-level governance research among graduate students. Allied with the Forum of Federations and founding partner, Institute of Intergovernmental Relations at Queen's University; Federal Governance aims to contribute to a global dialogue on federalism.

Co Chairs, Advisory Committee:

Publisher:

Managing Editor:

Associate Editors:
Rupak Chattopadhyay and Christian Leuprecht

Forum of Federations

(Rupak Chattopadhyay and Rod Macdonell)

Annegret Eppler

Joshua Cerovski, Dominic Heinz, Eva-Maria Maggi and Victoria Tait

\section{Terms of Use}

Your use of this Federal Governance article indicates your acceptance of Federal Governance's Terms and Conditions of Use, available at www.federalgovernance.ca/terms. Federal Governance's Terms and Conditions of Use provides that you may use Federal Governance content only for personal, academic and non-commercial use. Each copy of any part of this Federal Governance article must contain the same copyright notice that appears on the screen or printed page of such transmission. 


\section{Introduction}

Creative institutional design rather than adherence to rigid institutional structures and international principles is increasingly becoming a promising way of fostering reconciliation and political accommodation within ethnically divided societies (Reilly $2011,3)$. This article focuses on deviation from the 'one-person one-vote' principle in the Annan plan as a potential method of creative institutional design in Cyprus to overcome division. Although a seemingly natural method of political representation, deviation from one-person one-vote (OPOV) can allow for more effective participation of minorities, in this case the Turkish Cypriots, which may develop into cooperative relationships with other groups. Opponents of deviation argue it is undemocratic and dysfunctional, thus it may exacerbate conflict between groups.

Instances of group strife can pose problems for the establishment and maintenance of democracy (Lijphart 2004, 96). Proponents of OPOV and proceduralist democracy argue that the 'rules of the game' will allow groups a fair and equal chance of attaining power in the next elections, which is not only 'democratic' but will also reassure groups out of power. However, OPOV does not alleviate the problems for small minority groups that face permanent exclusion, lack effective representation or participation, such as the estimated $18 \%$ Turkish Cypriot minority in Cyprus. In situations of group conflict there is a tendency to conflate inclusion/exclusion in the government with inclusion/exclusion in the community (Horowitz, 1993: 18-19). Thus majoritarian democracy may not be able to accommodate minority groups, instead, adherence to OPOV may exacerbate existing cleavages and destabilize the political system (Loizides, 2010: 5).

In light of these observations deviation from the OPOV principle may be required. Deviation occurs in one of the most familiar institutional designs proscribed in situations of group conflict, and indeed in Cyprus, federalism. A common feature of the federalist political system is a bicameral legislature, where the lower chamber is based on representation by population, and the upper chamber on equal (or increased) representation of the constituent units, whose boundaries can be drawn to make national minorities regional majorities. Federalism's upper chamber often clearly deviates from the OPOV principle by weighting votes differently depending on the subnational entity of residence, usually over-representing smaller units. For example in the US Senate, California's approximately $37,000,000$ people have two representatives, the same number for Wyoming's approximately 545,000 people. Given that there is significant diversity, in size and demographics among units in almost all federations, federalism will necessarily deviate from OPOV. Indeed, forms of 'asymmetric federalism' that treat units differently in representation (and other ways) may be more apt in conflict regulation (Ghai, 2002: 158-159). In contrast to critics of the federal Annan plan Niyazi Kizilyurek (2007) postulates that Cyprus requires group- 
differentiated rights (including Turkish Cypriot over-representation in some institutions) to accommodate fears of Greek Cypriot domination (estimated $80 \%$ of the population), and the overall functionality of the plan. This article argues that deviation is required for the effective participation and articulation of group interests in central government, and thus political accommodation between Turkish Cypriots and Greek Cypriots.

\section{Federalism in Cyprus}

Federalism remains firmly rooted within the social discourse and political reality in Cyprus. Federalism emerged as the solution to the 'Cyprus problem' chiefly because of 'facts' established by recent Cypriot history. Cyprus represents a peculiar case whereby both nationalisms on the island did not seek nation-states on Cypriot soil. Both demonstrated an 'Anschluss-nationalismus' (union with the motherland), whereby the Greek Cypriots pursued enosis (union) with Greece as part of their anti-colonial struggle against British imperial rule, whereas nationalist Turkish Cypriot rhetoric stressed kinship with Turkey. Fearing for their security and identity in a potentially Greek state, the Turkish Cypriots advocated taksim (partition) for the north to be ruled by Turkey. Thus mutually antagonistic identities and nationalisms existed on the island.

The 1959 London-Zurich Agreements were signed between Britain, Greece and Turkey, granting a heavily curtailed "independence" to Cyprus, notably forbidding enosis and taksim in the 1960 constitution (Guelke, 2001). The new political arrangements were consociational, with a grand coalition, vetoes and proportionality (70,30 in most institutions). Independence had been the goal of neither of the communities, and both enosis and taksim ideologies continued to exert influence on political life (ibid). The 1960 arrangement accommodated separate collective identities without having constructed a common sense of citizenship (Kizilyurek, 2007). The arrangement effectively ended in 1963, when after debilitating deadlock, Greek Cypriot President Archbishop Makarios III proposed amendments to the constitution that would remove Turkish Cypriot veto rights and their over-representation in civil service and governmental institutions. This provoked many of the Turkish Cypriot minority fears of domination, sparking inter-communal violence and increased segregation with the Turkish Cypriots being forced into enclaves. Fighting between rival paramilitary groups EOKA (Greek Cypriot hardliners) and TMT (Turkish Cypriot hardliners), reported ethnic expulsions and cleansing, created numerous refugees and displaced persons. On 20 July 1974 the Turkish military invaded after a coup of Makarios by Greek Cypriot hardliners (EOKA B) with the support of the Greek junta. Turkey feared what the newly installed President Nicos Sampson may do to the Turkish Cypriots in pursuit of enosis, which Makarios had seemingly abandoned several years earlier. The result was the partition, with the Turks controlling $37 \%$ of land in the north of the island. Many Turkish 
Cypriots moved north into the homes of displaced Greek Cypriots who had fled south, and few Turkish Cypriots or Greek Cypriots remained on the 'wrong side' of the Green Line.

Subsequent searches for accommodation have focused on reunification of the island whilst allowing both Cypriot communities a degree of autonomy. Kizilyurek (2007) argues that any accommodation has to deal with fears of domination and separation, on a basis of equality, whilst recognizing both individual and collective rights. Federalism in the form a 'bi-zonal, bi-communal federation' emerged as the most viable solution. A federal state, bi-zonal in terms of territory and bi-communal in terms of its constitutional aspects, based on the political equality of two communities under shared sovereignty are the essential parameters of the negotiations (Sözen and Özersay, 2007: 125). Federalism's conflict regulating potential has been questioned chiefly because of the threat of secession and the problems intermingling communities pose to drawing entity boundaries (McGarry and O'Leary; 1993: 34; Nordlinger, 1972; O'Leary, 2001: 49-52). Nevertheless, these concerns are relatively minor in the Cyprus case. Firstly, Turkish Cypriot isolation due to the international community's rejection of the Turkish Republic of Northern Cyprus (declared in 1983) means any attempt to secede from a future federal Cyprus will be an unviable and unattractive option. Secondly, the 'facts on-the-ground' post-1974 and agreement from the two communities allow the possibility of creating two federal zones with Turkish Cypriot and Greek Cypriot majorities, but without restricting human rights and the right of return for refugees. Rather than establishing two separate zones, the federal arrangement proposed for Cyprus allows for refugee return and features a boundary re-adjustment, reducing the majority Turkish Cypriot zone. The right of return is particularly dear to Greek Cypriots wishing to return to the north. Greek Cypriot return could be linked to incentives for Turkish Cypriots, such as naturalization of Turkish settlers, creating a 'win-win' scenario for both communities. Turkish Cypriot demographic fears are further allayed by the fact that all 100,000 Greek Cypriot refugees and their descendants could be accommodated in Turkish Cypriot areas without rising above $27 \%$ of the population (Loizides and Antoniades, 2009). These parameters have been established in talks with the United Nations, through the High-Level Agreements of 1977 and 1979, the 'Set of Ideas' in 1989 culminating most recently in the Annan plans 2002-2004. The 'United Cyprus Republic' proposed by Annan would be an asymmetric federation with each national community enjoying autonomy and group-differentiated rights both within their federal units and at a national level. Opponents of its deviations from OPOV argue that it is undemocratic and dysfunctional with problematic implications for eventual reconciliation. This article looks at each claim in turn. 


\section{Deviation from the 'one-person one-vote principle' is undemocratic}

Although several researchers have attempted to measure democracy, there is little consensus on its definitions and principles (Kekic, 2007). Evaluating deviation in the Annan plan through binary 'undemocratic' or 'democratic' readings risks masking how deviation may satisfy some principles of democracy at the expense of others. Group conflict demands we make pragmatic choices about which measures of democracy we wish to address. Both (a) philosophical arguments and (b) international legal principles reflect the contested nature of this prioritization. This article argues that in situations of group conflict, 'effective participation' is a more salient requirement than procedural equality. Majoritarian conceptions of democracy in Cyprus are clearly problematic given its history and demographic make-up. Deviation from OPOV to ensure effective participation is not only democratic but by creating incentives for both parties to operate the settlement effectively, it can be reconciliatory through developing higher levels of interaction and cooperation.

\section{a) Philosophical Arguments}

Classical liberalism defends the OPOV principle on the grounds of procedural equality, whereby all individuals can vote and know that their vote counts equally. This allows for free and fair elections to take place, which are a prerequisite for democracy. Any deviation or mal-apportionment is a challenge to this democratic fairness and can be destabilizing (Snyder and Samuels 2001, 146-147). The right to vote is a universal and individual one, with a long lineage in the ideas of the Enlightenment and the French Revolution. OPOV is equal in the sense of 'sameness' rather than recognition of difference which classical liberals reject as unattainable (Rae 1981, 451). There is no need to exercise the right as a group because people's cultural membership and identities are protected by the common rights of citizenship and state neutrality (Barry 2000). Recognition in the political system may reify and institutionalize divisive group identities. Thus OPOV is democratic because it is procedurally fair and does not unequally privilege any group over another.

Richard Snyder and David Samuels $(2001,149)$ rail against the disproportionate translation of votes into seats: "Where formal electoral rules lead to unfair electoral results, even games that do abide by the rules may be undemocratic". While Snyder and Samuels were arguing for more stringent adherence to OPOV, a different school of academics use the same arguments against OPOV. They question whether OPOV affords disadvantaged minority groups effective representation (Kymlicka 1995; Phillips 1994). Effective participation is also a key tenet of democracy, so that deviation to achieve this goal can be considered democratic. Effective participation is also more salient in the democratic balance than classical liberal conceptions of procedural equality in the accommodation of group conflict. Within the liberal tradition, academics like Will Kymlicka argue that group rights are not necessarily incompatible with 
individual rights. Liberal multiculturalism argues for 'equality as difference', in that 'true equality requires not identical treatment, but rather a differentiated treatment in order to accommodate differential needs" $(1995,113)$. Differentiated treatment under Annan may include special rights beyond the common individual rights of citizenship which deviate from OPOV. Rather than the state remaining neutral, which Kymlicka (1995, 107-110) argues is incoherent as the state unavoidably promotes certain identities, the state should be 'evenhanded', sensitive rather than indifferent to competing claims for recognition (Carens 2000,12). Multiculturalism thus prioritizes different measures of democracy than classical liberalism, allowing for deviation from OPOV that may not be strictly procedurally fair and equal, yet ensures effective participation. An insightful article by Nicos Trimikliniotis $(2009,116)$ argues that treating these methods "as an undemocratic 'distortion' or 'deviation' from the majoritarian principle of 'the will of the people' is to deny any accommodation to the problem". This article agrees, arguing effective participation, rather than the procedural equality of all groups under the Annan plan, is more likely to foster cooperation and reconciliation.

\section{b) International Legal Principles}

The international community and its norms can define the scope of possible solutions to group conflict problems. Norms are not static, yet they largely derive from legal principles. Ahmet Sözen (2004) argues that the Annan plan and the international community's approach to the Cyprus problem reflects the norm of territorial integrity and the desire to avoid further fragmentation of the international system, focusing its efforts on political accommodation and multi-ethnic co-existence. The international community will also have a normative bearing on whether deviation from the OPOV principle should be considered undemocratic. Oddly, Annan appears 'out of step' with international norms and texts on OPOV. The international community largely echoes the classical liberalist position. For example, the Venice Commission's report (2008: 3) on the permissibility of 'dual voting' for national minorities, argued that the Council of Europe would be ill-advised to weaken "the fundamental principle of democracy: equality of the right to vote". Dual voting was rejected as it afforded some voters greater weight than others, compromising the guarantee of 'universal and equal suffrage' under Article 25 of the UN International Covenant on Civil and Political Rights. International legal principles implicate deviation as undemocratic on the basis of weakening equality afforded to voters by the OPOV principle. Nevertheless, the Venice Commission allows that the OPOV principle is not absolute:

"Exceptions, restrictions and variations are accepted if their purpose is lawful and necessary and their method chosen is proportional to the outcome sought" (Durrieu 2007, 7; bold and underlining in original)

It is not difficult to imagine that deviation as a method of political accommodation may warrant the 'exception' label. In addition, Dr. Fernand de Varennes argues that the 
right of equal suffrage is "not so rigid" in international law. Article 2 of the UN Declaration on the Rights of Persons Belonging to National or Ethnic, Religious and Linguistic Minorities clarifies how this right should be interpreted in relation to minorities. Articles 2(2) and 2(3) state that minorities have the "right to participate effectively" (1998; my emphasis) in public life and in decisions at national and regional levels. Effective participation of minorities also appears in Article 15 of the Framework Convention for the Protection of National Minorities, and in the Venice Commission's report itself:

"According to the Court of Human Rights, such alternatives permit difference treatment of minorities to enable them to participate effectively in public life" (Durrieu, 2007: 7; bold and underlining in original)

The Commission proclaims that this is the "key to a stable and peaceful society" (Durrieu, 2007: 9). International legal principles are thus not absolute with regards to deviation. The emphasis on effective participation evokes liberal multiculturalist arguments. It is perhaps a curiosity that with so many federations throughout the world that deviation is still considered an "exception". Rigid adherence to international legal texts may prevent creative institutional design in situations of group conflict. While the particular deviations in Cyprus could be considered 'exceptional' to that case, the international community should be willing to consider deviation in general as a measure of accommodation in group conflict. Annan could be representative of the international community moving away from rigid adherence toward creative institutional design. More recent negotiations in Cyprus also point in this direction, where it has been proposed that Greek Cypriots become a $20 \%$ electoral minority of Turkish Cypriots in the election of the Vice President to match the Turkish Cypriot participation in the election of President (Loizides 2010, 1). This article argues that the effective participation of minorities, such as the Turkish Cypriots is more pertinent for political accommodation than the procedurally equal OPOV principle, and that deviation to achieve this through over-representation in federal institutions should not be considered undemocratic nor necessarily an exception.

\section{Deviation from the 'one-person one-vote principle' is dysfunctional}

It may seem counter-intuitive to examine the functionality of deviation from the OPOV principle in the Annan plan. It has yet come to fruition after $76 \%$ of Greek Cypriots rejected it in the 2004 referendum. Furthermore, political scientists are wary about overstating the potential effects that institutions may have on political behaviour and thus its presumed functionality (Bieber 2010). Nevertheless, Giovanni Sartori contends that constitutions are 'predictable' because they act as pathways which structure and discipline decision-making (in Trimikliniotis 2009, 116). This article is more inclined 
towards Sartori's argument. The ethos underlying the Annan Plan is worth quoting at length as it influences the functionality assessment:

"My [Kofi Annan's] proposal to find a way through this cluster of issues was inspired by the need to find a form of government which (a) reflected and guaranteed the political equality of Greek Cypriots and Turkish Cypriots but also reflected in a democratic manner the significantly larger numbers of Greek Cypriot citizens; and (b) carried cast-iron guarantees against domination while ensuring that the government would function effectively" (UNSC 2003, 18; emphasis G.M.)

Annan thus tries to find a balance in terms of representation of the two communities despite demographic disparities and preventing domination via veto rights. These are not the only federal arrangements under the plan but they are arguably most crucial to Annan's reconciliatory potential. The integrationist critique that by institutionalizing ethnicities we reify and exacerbate these identities is noteworthy (Horowitz 2002). However, this article is of the view that non-recognition institutionally of the rival communities in Cyprus, particularly the Turkish Cypriots, would make the federal institutions dysfunctional, intensifying Turkish Cypriot fears of domination. The balance underlying Annan's ethos justifies deviation from the OPOV principle in certain instances in order to enhance the functionality of the agreement.

The Annan plan is typical of other federal and consociational institutional designs that deviate from OPOV in terms of proportionality through disproportionate representation in favour of the minority (Lijphart 1979; Schneckener 2002, 220). Indeed, "federal failures primarily occur because minorities continue to be outnumbered at the federal level of government" (McGarry and O'Leary 1993, 34). Annan compensates for the demographic inferiority of the Turkish Cypriots, in the legislature whereby the 48member upper chamber (Senate) of the bicameral legislature is composed equally of both communities and Turkish Cypriots are guaranteed at least $25 \%$ of the seats in the 48-member Chamber of Deputies (UNSC 2003, 19). Seat allocations or thresholds that over-represent the minority are not uncommon e.g. in Slovenia, Italian $(0.11 \%$ of the population) and Hungarian $(0.32 \%)$ minorities have dual voting rights whereby they vote in the general election as well as special lists that guarantee a Italian and Hungarian member of parliament (Venice Commission 2008, 3).

The 'grand coalition' in the executive Presidential Council is also disproportionate, over-representing the Turkish Cypriots, with 2 out of the 6 members. The rotating chair principle allows a Turkish Cypriot member of the Council to represent the Council as Head of State a third of the time. Inclusion in the Executive and rotating chairs are not without international precedent in group conflict. In Northern Ireland, the 10-member Executive Committee's positions are allocated via the d'Hondt mechanism which promotes inclusion of both communities and the moderate and hardline positions within those communities (Wilson 2001, 74). The Dayton Agreement stipulated that the chair 
of the Presidency of Bosnia and Herzegovina was to rotate between the elected Bosniak (43\%), Serb (31\%) and Croat (17\%) representatives on 8-month terms for four years. Despite some turbulence in the formative years of both cases, each arrangement has remained in effect, indicating the functionality of each arrangement, if not allaying integrationist fears of its reconciliatory potential.

Additionally, the Annan plan deviates from OPOV in representation by recognizing the Turkish Cypriot minority as a majority in its federal sub-unit. The practice of redistricting is commonplace in federal arrangements (Kymlicka 1995), but the guarantee of segmental autonomy in Cyprus has been criticized for its effective recognition of an 'illegitimate entity' in the north of the island and by 'ratifying' the immoral means that achieved it (Anderson 2008; Emilianides 2009, 97). Nevertheless, the Greek Cypriots made the 'historic compromise' by accepting federal arrangements, thus while objections to the means that established Greek Cypriot and Turkish Cypriot near-homogeneous federal units are important moral arguments, federal institutions are the reality (Solomides 2010). The over-representation of Turkish Cypriots can be seen as the result of the balance sought in Annan between political equality of Turkish Cypriots and Greek Cypriots whilst recognizing Greek Cypriot demographic superiority (UNSC 2003, 18). Klearchos A. Kyriakides (2009, 68-69) argues that the Annan plan is imbalanced and "intentionally dysfunctional" because it 'blunts' the supremacy of the majority. Indeed, the 1960 constitution over-representation has been held partially responsible for its downfall (Schneckener 2002). In contrast, this article argues the plan is functional because of the nuanced balance outlined, ensuring the Turkish Cypriots interests are effectively recognized and cannot be outvoted by the majority. Annan also provides enough incentives for Greek Cypriots to accept Turkish Cypriot over-representation and veto rights.

One of the most contentious aspects of the functionality of the Annan plan is the provision of veto rights because they "blunt" the supremacy of the Greek Cypriot majority. According to Annan (UNSC 2003, 15), the idea that no decision could be taken by one constituent state and no single person could veto decisions and block the functionality of the state "run like a golden thread throughout the plan". Veto rights are more commonly associated with consociationalism, yet federalism may also contain its own veto points. The informal 'entity veto', or sub-state veto over central state proposals are common to most federations e.g. amendment of the states constitution may require entity consent. Annan goes further than most federations in this regard, providing vetoes via special majorities of two-fifths on measures deemed of 'vital interest' and on the Presidential Council where any majority must include at least one Turkish Cypriot (ibid: 19). Achilles C. Emilianides $(2009,101)$ argues that this latter veto prevents a functional decision-maker in the executive, causing deadlock to become normal. Although veto rights are applicable to both Greek and Turkish Cypriots, they are inevitably weighted towards the minority. The power to block 
decisions and legislation by an $18 \%$ minority seems prima facie a potentially dysfunctional deviation from OPOV. Presidential and Vice-Presidential veto powers under the 1960 constitution were blamed for blockage and paralysis that ultimately brought down the political system (Schneckener 2002, 222).

Nevertheless, political institutions must be contextualized. Veto rights, groupdifferentiated in the sense they are likely to be utilized more by the Turkish Cypriots, are realistic about the situation in Cyprus. Furthermore, in recognition of instances of deadlock, the Supreme Court comprising an equal number of Cypriot judges from the two communities and foreign judges appointed by the UN would intervene (Loizides 2009, 85). This system has been criticized for violating Cyprus's sovereignty and placing too much power in the hands of unelected judges (Anderson 2008; Kyriakides 2009). Whilst this judicial arbitration proposal is not ideal, it is not uncommon for the legal branch of government to have such a powerful say in federal systems and such mechanisms have been used effectively elsewhere. In South Tyrol, parliamentary language groups can call upon the Italian constitutional court if a law is passed against the will of two-thirds of one language group (Schneckener 2002, 221). Loizides (2009, 86) argues that minority vetoes could add to the functionality of a peace settlement, clarifying "who to listen to, to what extent and under what circumstances". Veto rights can thus have a preventative effect, inducing accommodation by making the costs of dysfunctional and uncooperative behaviour high, incentivizing better relationships between the groups. Moreover, the Turkish Cypriot veto has historical precedent from 1960. Repudiation of these rights would be a serious breach of trust, creating instability and undermining the functionality of agreement (Kymlicka 1995, 116-119). Again Annan sought a balance, providing veto rights that deviate from OPOV as guarantees against domination while ensuring that the government would function effectively by inducing cooperation and fostering reconciliation, providing an arbitration mechanism if deadlock arose (UNSC 2003, 18).

\section{Conclusion}

This article argues that deviation from the OPOV principle within the federal framework of the Annan plan can be both democratic and functional. Furthermore, deviation can contribute to reconciliation by the effective participation of both communities which will develop better relationships between the communities. However, deviation should be context-specific in regard to its methods of accommodation (Bieber and Wolff 2005. 362; Carens 2000, 14; Kymlicka 1995, 110 and 141), with the proposals in the Annan plan unlikely to be replicated verbatim in other cases of group conflict. Certainly a 'one size fits all' approach is not recommended. Central to the argument of this article is the need for creative institutional design and deviation from OPOV in situations of group conflict. OPOV is compatible with democracy in the abstract but not conducive to 
multiethnic inclusiveness, creating instability (Horowitz 1993, 28). With regard to the 'deviation as undemocratic' question, this article argues that effective participation is more pertinent in cases of group conflict than the procedurally fair and equal measure embodied by OPOV. The balance in prioritization of these measures finds contending voices in philosophical arguments and international legal principles. Crucially, the Annan Plan in Cyprus does deviate from the principle in several instances of its architecture. Admittedly, federalism and mechanisms for accommodating group conflict that deviate from OPOV have mixed records elsewhere (Bieber 2010; Grant 2007). The challenge for Cyprus and the Annan plan is to ensure that groupdifferentiated rights, such as deviation from OPOV, can be reconciled with a common political culture that binds federal states (Kizilyurek 2007). This article argues that operation of Annan's federal arrangements is the most likely method of fostering such an identity. Conclusive evidence of the functionality and reconciliatory potential of deviation and federalism will only be established 'on-the-ground' and several years after its implementation. If both communities operate the federal settlement with an ethos of good faith and willingness to compromise, the balance within the Annan plan and its deviations from OPOV are a promising method of political accommodation for the Cyprus problem. 


\section{References}

[1] ANDERSON, P. 2008. The Divisions of Cyprus [online]. [Accessed 19 April 2010]. Available from: http://www.Irb.co.uk/v30/n08/perry-anderson/the-divisions-ofcyprus

[2] BARRY, B. 2000. Culture and Equality: An Egalitarian Critique of Multiculturalism. Cambridge: Polity Press.

[3] BIEBER, F. and S. WOLFF. 2005. Introduction: Elections in Divided Societies. Ethnopolitics. 4 (4), pp. 359-363.

[4] BIEBER, F. 2010. Making Consociationalism Work? The Failure of Consociational Reform in Bosnia. In: Violent Conflict and Societies in Transition, 14 May 2010, Queen's University Belfast. Available from: http://vimeo.com/11780664

[5] CARENS, J. H. 2000. Culture, Citizenship, and Community: A Contextual Exploration of Justice as Evenhandedness. Oxford: Oxford University Press.

[6] DE VARENNES, F. 1998. Towards Effective Political Participation and Representation of Minorities. Working Paper.

[7] DURRIEU, J. 2007. Comments on the note of the OSCE High Commissioner on National Minorities to a Venice Commission study on Dual Voting for Persons Belonging to National Minorities. (CDL-EL(2007)025). Strasbourg.

[8] EMILIANIDES, A. C. 2009. Contra: Constitutional Structure of the Annan Plan. In: A. VARNAVA and H. FAUSTMANN (eds). Reunifying Cyprus: The Annan Plan and Beyond. London: I. B. Tauris \& Co Ltd, pp. 95-106.

[9] GHAl, Y. P. 2002. Constitutional Asymmetries: Communal Representation, Federalism and Cultural Autonomy. In: A. REYNOLDS (ed). The Architecture of Democracy: Constitutional Design, Conflict Management, and Democracy. New York: Oxford University Press, pp. 141-170.

[10] GRANT, T. D. 2007. The Dayton Settlement in Bosnia and Herzegovina as Post-Conflict Model: Lessons for Cyprus. In: The Cyprus Conflict: Looking Ahead, 7/8 May 2007, Eastern Mediterranean University. Available from: http://www.cypruspolicycenter.org/haber oku.asp?haber=57

[11] GUELKE, A. 2001. Northern Ireland and Island Status. In: J. McGARRY (ed). Northern Ireland and the Divided World: Post-Agreement Northern Ireland in Comparative Perspective. Oxford University Press, pp. 228-252.

[12] HOROWITZ, D. L. 1993. Democracy in Divided Societies. Journal of Democracy. 4 (4), pp. 18-38.

[13] HOROWITZ, D. L. 2002. Constitutional Design: Proposals Versus Processes. In: A. REYNOLDS (ed). The Architecture of Democracy: Constitutional Design, Conflict Management, and Democracy. New York: Oxford University Press, pp. 15-36.

[14] HOROWITZ, D. L. 2003. Electoral Systems: A Primer for Decision Makers. Journal of Democracy. 14 (4), pp. 115-127. 
[15] KEKIC, J. 2007. The Economist's Intelligence Unit's index of democracy [online]. [Accessed 23 April 2010]. Available from: http://www.economist.com/media/pdf/Democracy Index 2007 v3.pdf

[16] KIZILYUREK, N. 2007. Historical and Political Basis of Federalism in Cyprus. In: The Cyprus Conflict: Looking Ahead, 7/8 May 2007, Eastern Mediterranean University. Available

from:

http://www.cypruspolicycenter.org/haber oku.asp?haber $=57$

[17] KYMLICKA, W. 1995. Multicultural Citizenship: A Liberal Theory of Minority Rights. Oxford: Oxford University Press.

[18] KYRIAKIDES, K. A. 2009. Contra: The Political Workability of the Annan Plan. In: A. VARNAVA and H. FAUSTMANN (eds). Reunifying Cyprus: The Annan Plan and Beyond. London: I. B. Tauris \& Co Ltd, pp. 68-81.

[19] LIJPHART, A. 1979. Consociation and Federation: Conceptual and Empirical Links. Canadian Journal of Political Science. 12 (3), pp. 499-516.

[20] LIJPHART, A. 2004. Constitutional Design in Divided Societies. Journal of Democracy. 15(2), pp. 96-109.

[21] LOIZIDES, N. G. 2009. Pro: An Appraisal of the Functionality of Annan Plan V. In: A. VARNAVA and H. FAUSTMANN (eds). Reunifying Cyprus: The Annan Plan and Beyond. London: I. B. Tauris \& Co Ltd, pp. 82-94.

[22] LOIZIDES, N. G. 2010. The Cyprus Negotiations and "the one-person one-vote principle": Examples of Divergence in Democratic Federations [online]. [Accessed 21 April 2010]. Available from: http://works.bepress.com/neophytos loizides/18/

[23] LOIZIDES, N. G. and M. A. ANTONIADES. 2009. Negotiating the Right of Return. Journal of Peace Research. 46 (5), pp. 611-622.

[24] McGARRY, J. and B. O'LEARY. 1993. The Politics of Ethnic Conflict Regulation: Case Studies of Protracted Ethnic Conflicts. London: Routledge.

[25] NORDLINGER, E. 1972. Conflict Regulation in Divided Societies. Cambridge, MA: Harvard University Centre for International Affairs.

[26] O'LEARY, B. 2001. The Elements of Right-Sizing and Right-Peopling the State. In: B. O'LEARY, I. S. LUSTICK and T. CALLAGHY (eds). Right-Sizing the State: the Politics of Moving Borders. Oxford: Oxford University Press, pp. 15-73.

[27] PHILLIPS, A. 1994. Dealing with Difference: A Politics of Ideas or a Politics of Presence?. Constellations. 1 (1), pp. 74-91.

[28] RAE, D. 1981. Two Contradictory Ideas of (Political) Equality. Ethics. 91 (3), pp. 451-456.

[29] REILLY, B. 2011 [awaiting publication]. Centripetalism [online]. [Accessed 28 May 2010]. Available from: http://ethnopolitics.org/isa/Reilly.pdf

[30] SCHNECKENER, U. 2002. Making Power-Sharing Work: Lessons from Successes and Failures in Ethnic Conflict Regulation. Journal of Peace Research. 39 (2), pp. 203-228. 
[31] SNYDER, R. and D. SAMUELS. 2001. Devaluing the Vote in Latin America. Journal of Democracy. 12 (1), pp. 146-159.

[32] SOLOMIDES, S. 2010. Bizonal, bicommunal federation: is it the right choice and what are the chances of success? [online]. [Accessed 29 May 2010]. Available from: $\quad$ http://www.cyprus-mail.com/opinions/bizonal-bicommunal-federation-it-rightchoice-and-what-are-chances-success/20100425

[33] SÖZEN, A. 2004. A Model of Power-Sharing in Cyprus: From the 1959 London-Zurich Agreements to the Annan Plan. Turkish Studies. 5 (1), pp. 61-77.

[34] SÖZEN, A. and K. ÖZERSAY. 2007. The Annan Plan: State Succession or Continuity. Middle Eastern Studies. 43 (1), pp. 125-141.

[35] TRIMIKLINIOTIS, N. 2009. Pro: Rethinking the Un-viability of the Constitutional Arrangement. In: A. VARNAVA and H. FAUSTMANN (eds). Reunifying Cyprus: The Annan Plan and Beyond. London: I. B. Tauris \& Co Ltd, pp. 107-121.

[36] UNITED NATIONS SECURITY COUNCIL (UNSC). 2003. Report of the Secretary-General on his mission of good offices in Cyprus. (S(2003)398).

[37] VENICE COMMISSION. 2008. Report on Dual Voting for Persons belonging to National Minorities. (CDL-AS(2008)013). Strasbourg.

[38] WILSON, R. 2001. The Executive Committee. In: R. WILSON (ed). Agreeing to Diagree?: A Guide to the Northern Ireland Assembly. Norwich: The Stationary Office, pp. 73-78. 